\title{
Prólogo
}

\section{Palabras del señor rector}

A nuestros lectores les hacemos una atenta invitación para que, en esta oportunidad, examinen la tercera edición de la revista Kóot - que tal vez ya está en sus manos - , que, como ya se ha mencionado, se especializa en las ciencias denominadas "de la cultura": la arqueología, la antropología y la historia; que tienen su presencia y permanencia en los museos del país y del mundo.

Para la Universidad Tecnológica de El Salvador es un verdadero logro contar en su recinto con el Museo Universitario de Antropología, MUA, que resguarda, precisamente, las riquezas arqueológicas y documentales, que se integran con las antropológicas, para contar nuestra interesante y valiosa historia.

Son de mucho interés los temas tratados en este número. Se centran en la importancia de los cambios que se van dando en la modernidad, contrastados con la permanencia de los vestigios socioculturales de nuestros ancestros, y en el espacio y estudio de que son objeto en el ámbito museístico.

Esta publicación es un aporte científico cultural en esta rama específica que la universidad, a través del MUA, desea hacer permanente y siempre actualizado. Para lograrlo es imprescindible la participación de profesionales dedicados y dispuestos ha dejar plasmadas en la página impresa sus experiencias y hallazgos. Aprovechamos para reiterarles nuestros agradecimientos, así como a la Dirección del museo, al equipo editorial y a la impresora.

El esfuerzo vale la pena, y el disfrute cultural de este tipo de conocimiento procesado es el mejor galardón para el trabajo bien logrado. Ese es el principal objetivo de Kóot. 


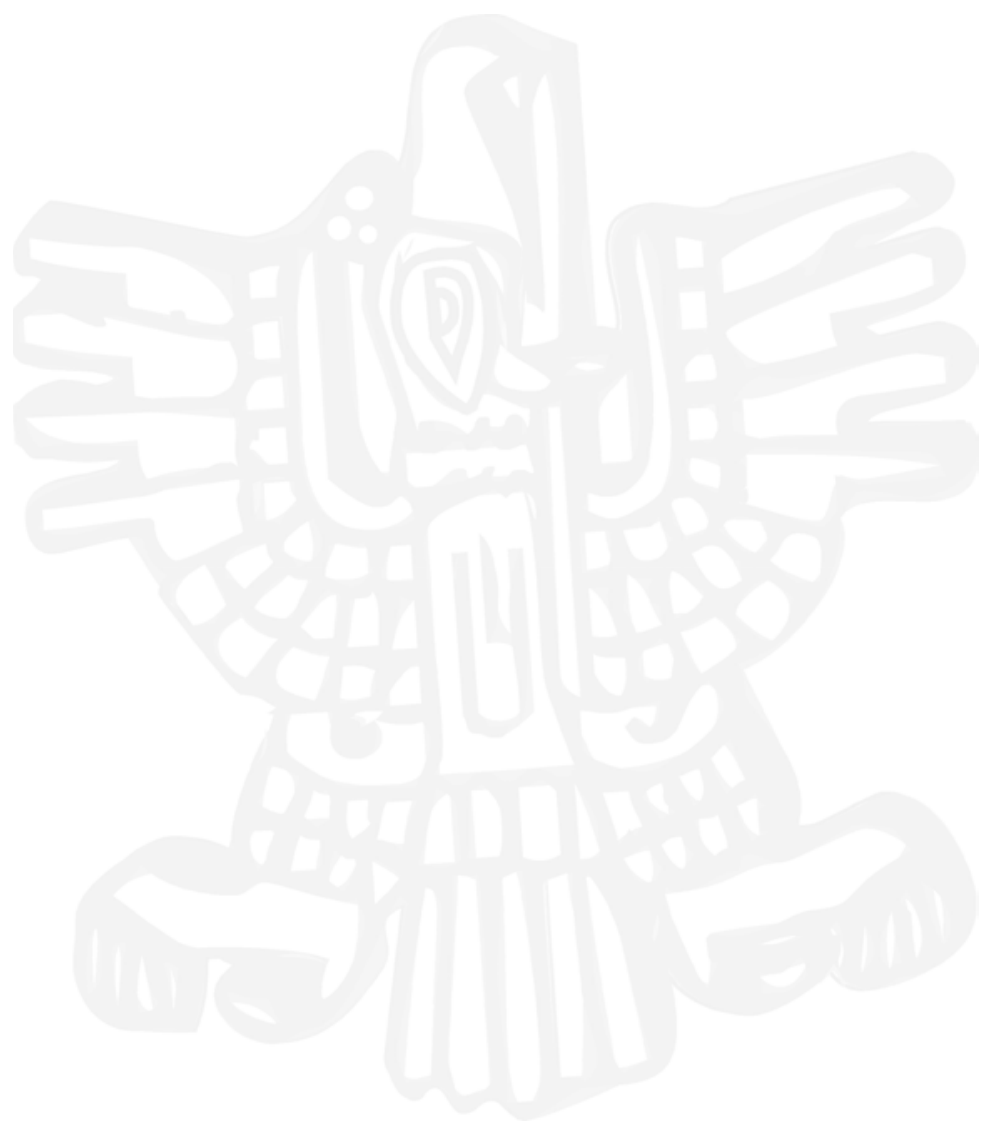

